\title{
PENGARUH MODEL PEMBELAJARAN EXPERIENTIAL LEARNING TERHADAP KEMAMPUAN MENULIS TEKS LAPORAN HASIL OBSERVASI SISWA KELAS VII SMP MUHAMMADIYAH 1 MEDAN TAHUN PEMBELAJARAN 2018/2019
}

\author{
Oleh \\ Uswatun Hasanah (uswatunhasanah0308@gmail.com) \\ Syahnan Daulay (daulaysyahnan@gamil.com) \\ Universitas Negeri Medan
}

\begin{abstract}
ABSTRAK
Penelitian ini bertujuan untuk mengetahui pengaruh penggunaan model pembelajaran experiential learning terhadap kemampuan menulis teks laporan hasil observasi siswa kelas VII SMP Muhammadiyah 1 Medan tahun pembelajaran 2018/2019. Populasi penelitian ini berjumlah 154 siswa. Dari 154 siswa, ditetapkan 30 siswa yang diambil secara acak. Metode yang digunakan dalam penelitian ini adalah metode eksperimen one group pretest posttest design. Instrumen yang digunakan untuk menjaring data adalah tes uraian. Pengujian hipotesis dilakukan dengan menggunakan uji " $t$ ". Data yang diperoleh menunjukkan bahwa kemampuan siswa dalam menulis teks laporan hasil observasi sebelum menggunakan model pembelajaran experiential learning masuk dalam kategori kurang dengan nilai rata-rata (mean) yang diperoleh siswa adalah 6,44, sedangkan kemampuan siswa menulis teks laporan hasil observasi sesudah menggunakan model pembelajaran experiential learning masuk dalam kategori baik dengan nilai rata-rata (mean) yang diperoleh siswa adalah 75,66. Selanjutnya, uji hipotesis menunjukkan $t_{\text {hitung }}(4,59)>t_{\text {tabel }}(1,60)$ pada taraf signifikan $\alpha=0,05$. Dengan demikian $H_{0}$ ditolak dan $H_{a}$ diterima, hal ini berarti ada pengaruh model experiential learning terhadap kemampuan menulis teks eksposisi siswa kelas VII SMP Muhammadiyah 1 Medan tahun pembelajaran 2018/2019.
\end{abstract}

Kata kunci: pengaruh, menulis teks laporan hasil observasi, model experiential learning

\section{PENDAHULUAN}

Berbahasa memiliki empat kemampuan yaitu menyimak, berbicara, membaca, dan menulis. Keempat aspek bahasa tersebut saling berkaitan satu sama lain. Pembelajaran bahasa biasanya diawali dengan menyimak, kemudian meniru, dan mengomunikasikan kembali. satu keterampilan berbahasa adalah 
keterampilan menulis. Keterampilan menulis bertujuan mengembangkan kemampuan siswa dalam menuangkan ide kedalam sebuah tulisan.

Salah satu jenis teks yang terdapat dalam pembelajaran bahasa Indonesia yaitu teks laporan hasil observasi. Teks laporan hasil observasi adalah teks yang berisi langkah-langkah atau tahapan yang harus ditempuh untuk mencapai tujuan. Dalam pembelajaran menulis teks laporan hasil observasi, siswa dituntut untuk mengetahui struktur, langkah-langkah, tujuan dan ciri kebahasaan yang dimiliki teks tersebut. Selain itu siswa dituntut untuk lebih kreatif dalam menuangkan ide dan gagasan kedalam teks laporan hasil observasi. Berdasarkan pendapat diatas, teks laporan hasil observasi merupakan teks yang berbentuk hasil laporan atau pengamatan yang sudah dilakukan pengamatan berdasarkan langkah-langkah, ciri, dan struktur yang dimiliki. Teks laporan hasil observasi adalah teks yang baru muncul dalam pelajaran bahasa Indonesia kelas VII Kurikulum 2013, masih banyak siswa yang kurang paham mengenai konsep teks laporan hasil observasi. Pengetahuan siswa tentang unsur-unsur dan langkah-langkah dalam menulis teks laporan hasil observasi pun masih sangat rendah. Jika pengetahuan siswa masih rendah mengenai teks laporan hasil observasi, maka kemungkinan untuk menghasilkan teks laporan hasil observasi yang baik akan sulit dicapai.

Menurut bapak Darwanto, M.Pd. Guru SMP Muhammadiyah 1 Medan kemampuan siswa dalam menulis teks laporan hasil obsevasi berdasarkan struktur, ciri kebahasaan, dan tujuan teks laporan hasil observasi masih rendah dengan persentase 55\%. Persentase ini menggambarkan bagaimana siswa menulis teks laporan hasil observasi pada saat ini.

Pada penelitian Anggraini (2017) yang berjudul "Kemampuan Menulis Teks Laporan Hasil Observasi Siswa Kelas VII SMP Negeri 29 Medan Tahun Pembelajaran 2016/2017" diperoleh hasil bahwa kemampuan siswa dalam menulis teks laporan hasil observasi masih tergolong rendah, pada aspek struktur dan ciri kebahasaan teks laporan hasil observasi. Ditandai Rata-rata siswa pada kondisi awal sebesar 58,6 dengan KKM (Kriteria Ketuntasan Minimal) sebesar 70. Pada siklus I nilai rata-rata siswa sebesar 5,88, dan pada siklus II sebesar 73,7. Masalah penelitian diambil dari pengalaman empiris bahwa kemampuan siswa 
dalam menulis masih rendah. Berdasarkan hasil penelitian di atas diperoleh pemahaman bahwa kemampuan siswa dalam menulis teks laporan hasil observasi masih di bawah kategori kurang. Hal ini disebabkan karena kemampuan siswa dalam memahami struktur dan ciri kebahasaan teks laporan hasil observasi masih rendah.

Salah satu cara yang bisa dilakukan untuk mengatasi rendah kemampuan siswa dalam menulis teks laporan hasil observasi adalah pengajaran yang dilakukan dengan kreatif. Guru berperan memberikan pelayanan untuk memudahkan siswa dalam proses pembelajaran. Agar dapat menjadi fasilitator yang baik seorang guru harus memiliki kemampuan yang baik dalam berkomunikasi dan berinteraksi dengan siswa. Peran guru sebagai fasilitator dalam proses belajar mengajar sangat dibutuhkan untuk keberhasilan belajar siswa. Guru harus menggunakan metode, teknik, dan model yang tepat dalam proses belajar mengajar, terutama dalam pelajaran menulis. Hal ini diperlukan agar siswa menjadi aktif dalam kegiatan belajar sehingga diperoleh hasil belajar yang baik. Salah satu cara yang dapat dilakukan untuk menciptakan suasana pembelajaran yang aktif adalah dengan melakukan inovasi. Inovasi tersebut berupa pengunaan dan pengembangan model pembelajaran. Adapun model pembelajaran yang akan digunakan peneliti yaitu model pembelajaran experiential learning.

Pembelajaran dengan model experiental learning diperkenalkan oleh David Kolb yang mendefinisikan belajar sebagai proses bagaimana pengetahuan diciptakan melalui perubahan bentuk pengalaman. Sehubungan dengan itu Fathurrohman (2015: 129) menyatakan, "Experiential Learning adalah proses belajar, proses perubahan yang menggunakan pengalaman sebagai model belajar atau pembelajaran bukan hanya materi yang bersumber dari buku atau pendidik."

Pada penelitian Sholihah (2016) berjudul "Pengaruh Model Experiential Learning terhadap Kemampuan Berpikir Kritis Siswa SMA Assa'adah Gresik Tahun Pembelajaran 2015/2016 ." diperoleh hasil bahwa model pembelajaran Experiential Learning berpengaruh signifikan terhadap kemampuan berpikir kritis siswa SMA Assaadah Gresik. Nilai rata-rata kemampuan berpikir kritis yang 
menggunakan model pembelajaran experiential learning lebih tinggi, yaitu sebesar 80,9, sedangkan kelas kontrol sebesar 71,2. Berdasarkan nilai rata-rata tersebut dapat disimpulkan bahwa model pembelajaran experiential learning dapat meningkatkan kemampuan berpikir kritis siswa. Berdasarkan penelitian di atas, maka dapat diperoleh pemahaman bahwa model experiential learning berpengaruh terhadap kemampuan berpikir kritis siswa, karena hasil belajar tanpa menggunakan model pembelajaran experiential learning masih tergolong rendah.

Berdasarkan hal tersebut, penulis ingin menggunakan model pembelajaran experiential learning sebagai salah satu pembelajaran aktif dalam menulis teks laporan hasil observasi. Dengan menggunakan pembelajaran aktif model pembelajaran experiential learning, peneliti berasumsi bahwa model pembelajaran tersebut akan lebih memudahkan peserta didik dalam menulis teks laporan hasil observasi. Untuk itu, peneliti mengangkat judul "Pengaruh Model Pembelajaran Experiential Learning terhadap Kemampuan Menulis Teks Laporan Hasil Observasi Siswa Kelas VII SMP Muhammadiyah 1 Medan Tahun Pembelajaran 2018/2019."

\section{METODE PENELITIAN}

Penelitian ini dilakukan di SMP Muhammadiyah 1 Medan yang berlokasi di Jl. Damak No. 3, Medan. Penelitian ini merupakan penelitian quasi eksperimen dengan model one group pretest posttest design. Sugiyono (2016: 2) berpendapat metode penelitian adalah cara ilmiah untuk mendapatkan data dengan tujuan dan kegunaan tertentu. Metode penelitian dipakai sebagai alat untuk membantu memecahkan masalah dan membuktikan hipotesis. Metode yang digunakan dalam penelitian ini adalah metode ekperimen dengan model pre-test post-test one group design.

Instrumen dalam penelitian ini adalah berupa tes penugasan untuk kerja dalam bentuk tes kemampuan menulis teks laporan hasil observasi. Tes ini dilakukan dengan pre-test post-test untuk mendapatkan data kemampuan menulis teks laporan hasil observasi setelah diadakan perlakuan dengan membandingkan hasil. Dalam penelitian ini data yang digunakan adalah data kuantitatif, dikatakan 
sebagai data kuantitatif karena gambaran datanya menggunakan ukuran, jumlah, atau frekuensi yaitu nilai kemampuan siswa.

Ada beberapa langkah yang akan dilakukan dalam penelitian untuk memperoleh data, yaitu: menstabulasi skor pre test, menstabulasi skor post test, mencari mean variabel hasil pre test, mencari mean variabel hasil post test, mencari standar deviasi variabel hasil pre test, mencari standar deviasi variabel hasil post test, mencari standar eror variabel hasil pre test, mencari standar eror variabel hasil post test, melakukan uji normalitas, dan melakukan uji homogenitas, dan melakukan uji hipotesis.

\section{HASIL PENELITIAN DAN PEMBAHASAN}

\section{A. Hasil Penelitian}

\section{Kemampuan Siswa Menulis Teks Laporan Hasil Observasi} Sebelum Menggunakan Model Pembelajaran Experiential Learning

Data yang diperoleh dari penelitian ini adalah data menulis teks laporan hasil observasi oleh siswa kelas VII SMP Muhammadiyah 1 Medan Tahun Pembelajaran 2018/2019 sebelum menggunakan model pembelajaran experiential learning. Nilai rata-rata atau mean 62 standar deviasi 13,83 dan standar error sebesar 2,57. Kemampuan menulis teks laporan hasil observasi sebelum menggunakan model pembelajaran experiential learning terbagi dalam empat kategori, yaitu sangat baik 0\%, kategori baik sebesar 23,33\%, kategori cukup sebesar 56,67\%, kategori kurang sebesar 20\%. Adapun hasil pre test menulis teks laporan hasil observasi siswa dapat dilihat berdasarkan kategori sebagai berikut.

Tabel 1

Identifikasi Kecenderungan di Kelas Pre-test

\begin{tabular}{c|c|c|c}
\hline Frekuensi & $\begin{array}{c}\text { Frekuensi } \\
\text { Absolut }\end{array}$ & Frekuensi Relatif & Kategori \\
\hline $86-100$ & 0 & $0,00 \%$ & Sangat baik \\
\hline $76-85$ & 7 & $23,33 \%$ & Baik \\
\hline
\end{tabular}




\begin{tabular}{c|c|c|c}
\hline $56-75$ & 17 & $56,67 \%$ & Cukup \\
\hline $10-55$ & 6 & $20 \%$ & Kurang \\
\hline & $\mathbf{3 0}$ & $\mathbf{1 0 0 \%}$ & \\
\hline
\end{tabular}

Berdasarkan data di atas, dapat diketahui bahwa kemampuan menulis teks laporan hasil observasi sebelum menggunakan model pembelajaran experiential learning termasuk dalam lima kategori, yaitu kategori baik sebanyak 7 orang atau 23,33\%, kategori cukup sebanyak 17 orang atau 56,67\%, kategori kurang sebanyak 6 orang atau 20\%. Identifikasi kecenderungan di kelas pre-test termasuk kategori cukup.

\section{Kemampuan Siswa Menulis Teks Laporan Hasil Observasi Sesudah} Menggunakan Model Pembelajaran Experiential Learning

Berdasarkan hasil penelitian terhadap siswa kelas VII SMP Muhammadiyah 1 Medan, diperoleh nilai rata-rata atau mean 75,6, standar deviasi 8,13, dan standar error sebesar 1,51. Kemampuan menulis teks laporan hasil observasi sesudah menggunakan model pembelajaran Experiential Learning terbagi dalam empat kategori, yaitu sangat baik 10\%, kategori baik sebesar 30\%, kategori cukup sebesar 60\%, kategori kurang $0 \%$. Adapun hasil posttest menulis teks laporan hasil observasi siswa dapat dilihat berdasarkan kategori sebagai berikut.

Tabel 2

Identifikasi Kecenderungan di Kelas Post-test

\begin{tabular}{c|c|c|c}
\hline Frekuensi & Frekuensi Absolut & Frekuensi Relatif & Kategori \\
\hline $86-100$ & 3 & $10 \%$ & Sangat baik \\
\hline $76-85$ & 9 & $30 \%$ & Baik \\
\hline $56-75$ & 18 & $60 \%$ & Cukup \\
\hline $10-55$ & 0 & $0 \%$ & Kurang \\
\hline & $\mathbf{3 0}$ & $\mathbf{1 0 0 \%}$ & \\
\hline
\end{tabular}

Berdasarkan data di atas, dapat diketahui bahwa kemampuan menulis teks laporan hasil observasi menggunakan model pembelajaran experiential learning termasuk dalam lima kategori, yaitu kategori sangat baik sebanyak 3 orang atau 
$10 \%$, kategori baik sebanyak 9 orang atau $30 \%$, kategori cukup sebanyak 18 orang atau $60 \%$, kategori kurang tidak ada atau $0 \%$, dan kategori sangat kurang tidak ada atau 0\%. Identifikasi kecenderungan di kelas post- test termasuk kategori baik.

\section{B. PEMBAHASAN}

\section{Kemampuan Siswa Menulis Laporan Hasil Observasi sebelum Menggunakan Model Pembelajaran Experiential Learning}

Penelitian ini merupakan eksperimen dengan menggunakan model one-group pre-test dan post-test. Data yang diperoleh dari penelitian ini adalah data menulis teks laporan hasil observasi oleh siswa kelas VII SMP Muhammadiyah 1 Medan Tahun Pembelajaran 2018/2019, yang menjadi sample adalah kelas VII Terpadu 5 dengan jumlah siswa sebanyak 30 orang.

Data awal mengenai kemampuan menulis teks laporan hasil observasi diperoleh melalui tes awal (pre-test) pada pertemuan pertama. Saat pre-test ini siswa diberikan kesempatan untuk menulis teks laporan hasil observasi sesuai dengan pengetahuan dan kemampuan mereka masing-masing.

Setelah dilakukan tes awal (pre-test), diperoleh nilai rata-rata kemampuan teks laporan hasil observasi siswa sebelum menggunakan model pembelajaran experiential learning yaitu 62 dengan katagori kurang. Apabila ditinjau dari KKM (Kriteria Ketuntasan Minimal), maka nilai rata-rata menulis teks laporan hasil observasi siswa termasuk tidak tuntas karena berada di bawah nilai 70 .

Kegiatan pembelajaran diawali dengan memacu semangat siswa agar mampu mengikuti pembelajaran dengan baik dan memiliki konsentrasi yang tinggi. Kemudian, guru melaksanakan proses pembelajaran yang harus dicapai. Selanjutnya, guru melaksanakan proses pembelajaran Teks Laporan Hasil Observasi. 
Guru menjelaskan pembelajaran mengenai teks laporan hasil observasi yang memuat isi, struktur, dan ciri kebahasaan. Kemudian, siswa mulai bertanya mengenai suatu hal yang belum mereka pahami. Setelahnya, guru kembali memberikan pertanyaan kepada siswa dan mengamati bagaimana siswa menanggapi masalah yang dihadapi. Guru memberikan satu contoh mengenai teks laporan hasil observasi berdasarkan buku paduan bahasa Indonesia SMP Kelas VII. Setelah itu siswa menulis teks laporan hasil observasi mengenai "kucing" yang akan menjadi tema dalam menulis sebuah teks laporan hasil observasi yang utuh.

Hasil rata-rata kemampuan menulis teks laporan hasil observasi sebelum menggunakan model pembelajaran experiential learning 62 dari jumlah siswa sebanyak 30 orang dengan nilai tertinggi 85 dan nilai terendah 25 sedangkan data dikontrubusikan dalam kategori baik sebanyak 7 orang atau 23,33\%, kategori cukup sebanyak 17 orang atau $56,67 \%$, kategori kurang sebanyak 6 orang atau 20\%. Identifikasi kecenderungan di kelas pre-test termasuk kategori cukup. Uji normalitas kelas pre-test sebelum menggunakan model pembelajaran experiential learning dengan uji lilifoers $\mathrm{L}_{\text {tabel }}=0,1566$. Dengan demikian ternyata $\mathrm{L}$ hitung $<\mathrm{L}_{\text {tabel }}$ yaitu $(0,161<0,1566)$ dengan demikian data pada kelompok pre-test berdistribusi normal.

Pada tahap pre-test ini siswa kurang memahami aspek-aspek yang harus diperhatikan dalam indikator menulis teks laporan hasil observasi yang berhubungan dengan isi, struktur, ciri kaidah kebahasaan. Redahnya hasil belajar siswa dalam menulis teks laporan hasil observasi ini disebabkan siswa masih berlatih dengen menggunakan model pembelajaran yang konvensial yang membuat mereka jenuh sehingga tidak ada keaktifan siswa belajar dalam kelas. Sebelum penerapan model experiential learning ini siswa berlatih untuk meningkatkan kemampuan menulis teks laporan hasil observasi hanya dengan menuliskan apa yang 
mereka tahu saja tanpa diberikan arahan yang menarik siswa umtuk berpikir secara logis atau sistematis.

\section{Kemampuan Siswa Menulis Laporan Hasil Observasi sesudah Menggunakan Model Pembelajaran Experiential Learning}

Hasil kemampuan menulis teks laporan hasil observasi diperoleh tes akhir atau post-test. Kegiatan pembelajaran diawali dengan membagai lembar kerja. Kemudian, setiap siswa ditugaskan memahami materi konsep dasar teks laporan hasil observasi dan mengidentifikasi isi, struktur dan ciri kaidah kebahasaan. Selanjutnya, guru melaksanakan proses pembelajaran dengen menggunakan model pembelajaran experiential learning dengen pendekatan saintifik. Setiap anggota kelompok mendapatkan materi yang sama yaitu tentang pengalaman. Guru menugaskan siswa mengamati melalui tayangan video kucing. Untuk kegiatan lebih lanjut guru menugaskan siswa untuk mengamati lingkungan sekitar mereka dalam melakukan kegiatan observasi agar menembah pengalaman siswa. Setelah itu, siswa dalam kegiatan ini siswa mengingatkan pengalaman kegiatan obsevasi dengan pembelajran teks laporan hasil observasi. Pada akhirnya pertemuan siswa ditugaskan berlatih menulis pengalaman kegiatan observasi mereka.

Setelah siswa dirasa cukup paham tentang konsep dasar, isi, struktur dan ciri kaidah kebahasaan teks laporan hasil observasi, kemudian dilanjutkan dengan berlatih menulis teks laporan hasil observasi dengan memperhatikan isi, strukturnya dan ciri kaidah kebahasaannya. Kemudian guru memerika hasil latihan siswa dan memperbaiki hal-hal yang kurang. Pada pertemuan terakhir guru menugaskan siswa untuk membuat teks laporan hasil observasi kembali sebagai tes akhir atau post-test.

Dari hasil post-test yang dikumpulkan oleh siswa, diperoleh nilai rata-rata kemampuan menulis teks laporan hasil observasi siswa sesudah 
menggunakan model pembelajaran experiential learning, yaitu 75,66 dengan katagori baik. Apabila ditinjau dari KKM (Kriteria Ketuntasan Minimal), maka nilai rata-rata menulis teks laporan hasil observasi siswa termasuk tuntas karena berada di bawah nilai 70 .

Hasil rata-rata kemampuan menulis teks laporan hasil observasi sesudah menggunakan model pembelajaran experiential learning 75,66 dari jumlah siswa sebanyak 30 orang dengan nilai tertinggi 90 dan nilai terendah 65 sedangkan data dikontrubusikan dalam yaitu kategori sangat baik sebanyak 3 orang atau $10 \%$, kategori baik sebanyak 9 orang atau 30 $\%$, kategori cukup sebanyak 18 orang atau $60 \%$, kategori kurang tidak ada atau $0 \%$, dan kategori sangat kurang tidak ada atau $0 \%$. Identifikasi kecenderungan di kelas post- test termasuk kategori baik. Identifikasi kelompok post-test ini termasuk normal dan termasuk dalam kategori yang baik. Uji normalitas kelompok post-test dengan uji lilifors $\mathrm{L}_{\text {tabel }}=0,1566$. Dengan demikian $\mathrm{L}_{\text {hitung }}<\mathrm{L}_{\text {tabel }}$ yaitu $(0,138<0,1566)$ ini membuktikan bahwa data dari kelompok post test berdistribusi normal.

Dengan demikian, model pembelajaran experiential learning memberikan pengaruh terhadap kemampuan menulis teks laporan hasil observasi. Hal ini sesuai pendapat Indriana (2011:90), menyatakan "experiential learning merupakan model yang bertujuan untuk mengembangkan pengetahuan dan keterampilan siswa melalui pengalaman." Melalui penerapan model ini dalam pembelajaran, hasil 
belajar siswa dapatt maksimal. Siswa juga dapat mengerti bahwa pengalaman dapat dikaitkan dengen pembelajaran bahasa Indonseia.

\section{Pengaruh Model Pembelajaran Experiential Learning terhadap Kemampuan Menulis Teks Laporan Hasil Observasi}

Sebagaimana disajikan pada hasil penelitian yang menunjukkan nilai rata-rata untuk kemampuan menulis teks laporan hasil observasi siswa pada tahap sebelum penerapan model pembelajaran experiential learning tergolong pada kategori kurang dengan nilai rata-rata 62 dibamdingkan dengan tahap sesudah diterapkan model pembelajaran experiential learning yang berkategori baik dengan niali rata-rata 75,66. Sehingga data tersebut disimpulkan bahawa model pembelajaran experiential learningBerpengaruh dalam kemampuan menulis teks laporan hasil observasi.

Hal ini sesuai dengan hasil yang diharapkan untuk meningkatkan hasil belajar siswa dan juga mencapai KKM yang sudah ditentukan. Model pembelajaran yang mengoptimalkan ketiga modalitas belajar yaitu Experiential Learning untuk menjadikan peserta didik merasa nyaman dan memaksimalkan penerimaan materi secara mereta dan untuk meningkatkan hasil belajar peserta didik. Model ini memberikan kesempatan kepada siswa untuk belajar langsung dengan bebas menggunakan pengalaman yang dimilikinya untuk mencapai pemahaman dan pembelajaran yang efektif. 
Berdasarkan data kelompok pre-test dan kelompok post-test memiliki varians yang homogen. Hal ini ditunjukkan sesuai dengan perhitungan $\mathrm{F}_{\text {hitung }}<\mathrm{F}_{\text {tabel }}$ yaitu 1,22 $<1,67$. Sehingga data kelompok pretest dan kelompok post test dapat dilanjutkan untuk diuji analisis hipotesis.

Hasil penelitian menunjukkan bahwa rata-rata kemampuan menulis teks laporan hasil observasi sesudah menggunakan model pembelajaran experiential learning lebih tinggi atau lebih baik dari kemampuan menulis teks laporan hasil observasi sebelum menggunakan model pembelajaran exoeriential learning. Hal ini menunjukkan bahwasannya penggunaan model pembelajaran experiential learning efektif digunakan untuk membantu siswa terhadap pembelajaran menulis teks laporan hasil observasi pada siswa kelas VII SMP Muhammadiyah 1 Medan Tahun Pembelajaran 2018/2019.

Hal ini dibuktikan dengan diberikan perlakuan yang berbeda antara kelompok pre-test dan kelompok post-test. Kelompok pre-test siswa hanya diberi kesempatan untuk menulis teks laporan hasil observasi sesuai dengan pengetahuan dan kemampuan mereka masing-masing mengenai contok yang sudah diberika oleh gurunya. Sementara di kelompok posttest siswa diberi kesempatan untuk menulis teks laporan hasil observasi dengan bantuan model pembelajaran experiential learning dan kemudian siswa mempratikkan model tersebut.yang diharapkan dapat mendorong kemampuan siswa dalam kemampuan menulis mereka sehingga siswa mampu menulis sebuah tulisan yang baik dan benar dalam menulis teks 
laporan hasil observasi. Pembuktian lainnya juga diperoleh dari hasil uji hipotesis bahwasannya $t_{\text {hitung }}$ lebih besar dari $t_{\text {tabel }}$ yaitu 4,59>1,67 maka hipotesis ha diterima yang membuktikan adanya pengaruh yang signifikan terhadap kemampuan menulis teks laporan hasil observasi sesudah menggunakan model pembelajaran experiential learning.

\section{PENUTUP}

Berdasarkan hasil penelitian dan pembahasan yang telah diuraikan pada bab sebelumnya maka dapat disimpulkan. Kemampuan menulis teks laporan hasil observasi sebelum menggunakan model pembelajaran experiential learning pada kelas VII SMP Muhammadiyah 1 Medan Tahun Pembelajaran 2018/2019 menunjukkan hasil dengan nilai tertinggi 85 dan nilai terendah 25 yang diperoleh dari 30 sampel, yang memiliki nilai rata-rata 62 dan berada pada kategori cukup. Data kelompok pre-test berstatus normal dan homogen.

Kemampuan menulis teks laporan hasil observasi sesudah menggunakan model pembelajaran experiential learning pada kelas VII SMP Muhammadiyah 1 Medan Tahun Pembelajaran 2018/2018 yang menunjukkan hasil dengan nilai tertinggi 90 dan nilai terendah 65 dari 30 sampel yang memiliki nilai rata-rata 75,66 dan berada pada kategori baik. Data kelompok post-test berstatus normal dan homogen.

Terdapat pengaruh yang signifikasn terhadap penggunaan terhadap model pembelajaran experiential learning kemampuan menulis teks laporan hasil observasi pada siswa kelas VII SMP Muhammadiyah 1 Medan Tahun Pembelajaran 2018/2019. 
Saran yang dapat disampaikan 1) Hasil penelitian ini menunjukkan bahwa model pembelajaran experiential learning berpengaruh positif pada kemampuan menulis teks laporan hasil observasi. Oleh karena itu, model pembelajaran ini disarankan digunakan oleh guru bahasa Indonesia untuk meningkatkan keterampilan menulis teks laporan hasil observasi. 2) Perlunya dilakukan penelitian lanjutan oleh peneliti lain guru memberi masukan yang konstruktif bagi dunia pendidikan pada pembelajaran berbasis teks dalam kurikulum 2013. 3) Penelitian ini dapat menjadi bahan rujukan bagi peneliti lain dalam meneliti permasalahan yang relevan.

\section{DAFTAR PUSTAKA}

Anggraini, Nanda. 2017. Kemampuan Menulis Teks Laporan Hasil Observasi Siswa Kelas VII SMP Negeri 29 Medan Tahun Pembelajaran 2016/2017. Skripsi. Medan. UNIMED.

Indriana, Dina. 2012. Mengenal Ragam Gaya Pembelajaran Efektif. Yogyakarta: DIVA Press.

Fathurrohman, Muhammad. Model-Model Pembelajaran Inovatif. Yogyakarta: Arr-ruz Media

Nurgiantoro.2012. Penilaian Dalam Pembelajaran Bahasa dan Sastra. Yogyakarta: BPFE.

Sholiah, Mar'atus, dkk. Pengaruh Model Experiential Learning terhadap Kemampuan Berpikir Siswa SMA. Jurnal Pendidikan vol (1). Hlm 20962100

Sugiyono, 2016. Metode Penelitian Kuantitatif, Kualitatif, dan R\&D. Bandung: Alfabeta. 